\title{
ALGUNS PRECEITOS DA INVENÇÃO E ELOCUÇÃO METAFÓRICAS DE EMBLEMAS E EMPRESAS
}

\author{
João Adolfo Hansen \\ Universidade de São Paulo \\ joaoadolfohansen@gmail.com
}

RESUMO / ABSTRACT

$\mathrm{O}$ texto trata de dois gêneros mortos, emblema e empresa, especificando os preceitos da invenção do corpo (a imagem) e da alma (o discurso) de ambos que são legíveis em obras de Andrea Alciato, Horapolo, Valeriano, Francesco Colonna, Paolo Giovio, Emanuele Tesauro e, principalmente, no "Prólogo" de Iconologia, de Cesare Ripa. Os tratadistas opõem seus gêneros, considerando que são os usos que determinam sua diferença. $\mathrm{O}$ emblema sempre é definido como figuração de noções de validade coletiva. Quanto à empresa, figura um propósito heróico particular. No emblema, o mote que encima a alma e o corpo indica que é documento moral de sentido deliberativo ou aconselhamento da ação futura. O emblema também figura casos heróicos, ajuizando-os judicialmente e louvando-os epiditicamente como ações exemplares a serem imitadas por todos. Quanto à empresa, seu uso é individual e aristocrático, devendo ser aguda e equívoca, com a brevidade que obscurece a qualidade do que é figurado. Logo, o emblema sem imagens pintadas permanece emblema, bastando a alma (discurso) para representar publicamente o que se pretende figurar (como ocorre na primeira edição de Emblemata, de Alciato), enquanto a empresa nunca pode dispensar a imagem, pois sem ela o mote fica sem argumento de semelhança.

Palavras chaves: emblema, empresa, mote, cuerpo, alma, res picta, alegoria.

This text is about two dead genres, emblem and device. It specifies the precepts of the invention of the body (the image) and soul (the discourse) of both emblem and device, found in the works of Andrea Alciato, Horapolo, Valeriano, Francesco Colonna, Paolo Giovio, Emanuele Tesauro and especially in the "Preface" of Cesare Ripa's Iconología. The writers oppose their genres, considering that it is their usages which determine their differences. The emblem is always defined as the depiction of notions of collective validity, while the device depicts a purpose that is both particular and heroic. In the emblem, the motto that soul and body have, indicates that 
it is a moral document of deliberative sense or advice about future actions. The emblem also depicts heroic deeds, judging them judicially and praising them epideictically as exemplary actions that should be followed by everybody. As regards the device, its usage is individual and aristocratic. The device must be clever, equivocal and it has to be brief enough in order to darken the traits of what is being depicted. Therefore, without painted images the emblem is still an emblem, given that only the soul (discourse) is needed to publicly represent what is tried to be depicted (as, for instance, in the first edition of Alciato's Emblemata), while the device can never dispense with the image, given that without the image the device is left with no arguments of similarity.

KEY WORDS: emblem, device, motto, body, soul, allegory.

"... donde no hay cuerpo, le representan a la vista" (Fray Juan de Santa María. Tratado de República y Policía cristiana ... 28-29).

Em 1531, Heinrich Steyner, editor de Augsburg, resolveu acrescentar xilogravuras à reedição de Emblemata, livro de epigramas latinos do piemontês Andrea Alciato ${ }^{1}$. Na primeira edição de 1521, Alciato publicara somente os textos em que o destinatário visualiza imaginariamente as pequenas cenas compostas como écfrases e descrições de coisas, personagens e ações naturais, históricas e fabulosas. A iniciativa de Steyner tornava visível o ut pictura poesis horaciano que é diretamente legível, por exemplo, no Emblema IX, "Pinte-se a Honra em pé, velada com um manto púrpura"; no Emblema XIII, "A leoa que vês pintada é a fortaleza de Cécrope"; ou no LXXI, "assim pintam a inveja". As imagens que Steyner juntou à segunda edição não eram simples ilustrações dos epigramas, mas res pictae, como então se dizia nas discussões sobre a excelência das artes e a competição entre elas, "coisas

As xilogravuras foram feitas por Jörg Breu e anexadas sem o consentimento de Alciato, que se mostrou indiferente à adição de imagens, mas reclamou dos muitos erros dos textos. Em 1534, Emblemata foi reeditado em Paris por Chrétien Wechel, que continuou a acompanhá-lo por gravuras. Wechel sistematizou o modo de associar o texto e a imagem, agrupando no espaço fechado de cada página esquerda os três elementos que passariam a ser constantes nos livros de emblemas: o título (inscriptio), a gravura (figura) e o epigrama (subscriptio). Na página da direita, pôs a tradução do título e do epigrama. A partir da reedição de 1551, feita em Lyon, as reedições retomaram a ordem temática com que o editor Barthélemy Aneau dispõe os emblemas, propondo o uso de Emblemata como repertório de lugares-comuns. Cf. Chatelain 71-73. 
pintadas significantes", figurando metaforicamente os mesmos lugares-comuns retóricos desenvolvidos neles.

Na segunda edição e nos incontáveis livros de emblemas feitos a partir dela, os epigramas passaram a designar as res pictae e a significar os lugarescomuns das autoridades imitadas em suas imagens. Lendo-vendo o emblema, o leitor-espectador ocupa o lugar simbólico do destinatário, devendo como ele lembrar os lugares figurados nas suas três partes, o mote (título), a alma (texto ou epigrama), o corpo (imagem pictórica), para extrair algo de teor didascálico, sentença moral, exemplo religioso, preceito artístico, orientação política.

Desde a edição de 1531, o gênero teve um sucesso extraordinário; em alguns lugares, como Portugal e sua colônia brasileira, durou até o início do século $\mathrm{XIX}^{2}$, quando finalmente morreu, transformando-se num daqueles fósseis intelectuais de que Paolo Rossi fala em seu livro sobre as chaves universais (Rossi, Clavis Universalis). Desde o início, doutrinou-se a diferença do emblema e outro gênero, a empresa. Neste texto, especifico algumas matrizes do emblema, tratando de preceitos da sua invenção e elocução segundo o $u t$ pictura e das principais diferenças entre ele e a empresa.

Alciato explica porque fez o livro numa carta de 9 de janeiro de 1523 a seu amigo Francesco Calvi, o impressor romano:

Nessas festas de fim de ano, para agradar a Ambrogio Visconti, compus um pequeno livro de epigramas que intitulei Emblemas. Pois com cada um dos epigramas descrevo alguma coisa tirada ou da Natureza ou da História de maneira a fazer ver alguma coisa de elegante, a partir da qual os pintores, os ourives, os fundidores possam

\footnotetext{
No caso, pode-se lembrar o manuscrito Príncipe Perfeito. Emblemas de D. João de Solórzano, dedicado pelo bacharel Francisco António de Novaes Campos ao Príncipe Dom João, em 1790. Seus emblemas reproduzem os de um livro espanhol publicado por Solórzano Pereira em 1656, com pequenas alterações, mantendo o mote em latim, à maneira dos livros portugueses do gênero "espelho de príncipe", que fornecem exemplos de virtudes a serem imitadas por soberanos. Em Príncipe Perfeito, são as virtudes da Ética Nicomaquéia definidas catolicamente como meio-termo- temperança, fortaleza, prudência, justiça - que caracterizam o bom príncipe católico. O corpo dos emblemas representa a orientação do governo do rei católico pela Providência divina; epigramas ou poemas de quatro ou cinco versos, em latim, são a alma, que comenta o corpo. A única novidade é que o autor acrescentou sonetos em português, nos quais faz traduções das imagens do corpo e dos textos latinos da alma dos emblemas. Cf. Príncipe Perfeito. Emblemas de D. João de Solórzano.
} 
inventar essa espécie de objetos que chamamos brasão e que fixamos em nossos chapéus ou que tomamos por marcas, como a Âncora de Aldo, a Pomba de Frobênio e o Elefante de Calvi, sempre grávido, nunca parturiente (Alciat, ed.cit. 16-17).

Quando inventou os epigramas da edição de 1521 repetidos na de 1531, Alciato emulou os epigramas alexandrinos da Antologia palatina, de Planudes, publicada em Florença em $1494^{3}$. A forma breve e sentenciosa do epigrama é adaptada, nos emblemas, numa formulação que em geral tem duas partes: a primeira explica a história ou a fábula do texto por meio de narração, declaração, diálogo etc.; a segunda consiste na aplicação da história ou fábula ao que é significado no texto. No "Trattato degli emblemi", de $I l$ Cannocchiale Aristotélico (1654), Emanuele Tesauro propõe os epigramas alexandrinos como matéria da imitação do leitor que vá fazer emblemas, afirmando que os antigos já conheciam a arte de inventá-los:

Se leres as coleções dos escritores gregos antigos (a Antologia grega), terás nas mãos muitos e muitos epigramas sobre diversas imagens fabulosas ou históricas as quais, formando verdadeiros e agudíssimos emblemas, farão com que vejas que essa arte não é nova e que daqueles antigos mestres tomaram o lume os modernos engenhos (Tesauro, $I l$ Cannocchiale Aristotelico) ${ }^{4}$.

Os "modernos engenhos", que seguem século XVII adentro imitando a segunda edição do livro de Alciato, têm por referência também o Hieroglyphica, encontrado em 1419 na ilha grega de Andros por um florentino, Buondelmonti, e as muitíssimas interpretações dos textos dele feitas nos meios letrados e artísticos platônicos dos séculos XV e XVI. O livro é atribuído a Horapollon ou Horapolo (Hórus + Apolo), sacerdote egípcio alexandrino do século IV ou V d. C. Provavelmente apócrifo, Horapolo escreve um título breve, como

3 Cf. Anthologia diaphoron empigrammaton tou Maximou tou Planoudou Jo. Lascaris qui opus edidit Epigrammate graeco et eiusdem latina Epistola ad Petrum Mediceum 1494. Aldo Manúcio republicou os epigramas em Veneza. Cf. Florilegium diu. Epigrammatum in VII libros a Maximo Planude collectorum cum addminentis Aldi. Veneza, 1503. O livro foi reeditado em 1521.

Schopenhauer define o gênero "Dá-se ordinariamente o nome de emblema a desenhos alegóricos simples, acompanhados de um mote explicativo e destinados a ensinar de forma intuitiva uma verdade moral...”. Cf. Schopenhauer, A. O mundo como representação, I, III, 50: 317 . 
Eternidade, Alma, Tempo, e um comentário em que relaciona a noção expressa no título a uma imagem que os egípcios teriam usado para significá-la. Ao comentar o título Eternidade, fala do hieróglifo do ureus, a cobra de capelo que figura o Baixo Egito na coroa dupla dos faraós, propondo que os egípcios: "Para figurar 'eternidade', escrevem um sol e uma lua porque são eternos. Se querem escrever eternidade de outra forma, pintam uma serpente com a cauda escondida debaixo do resto do corpo" (Horapolo 43). Com o mesmo procedimento, interpreta a imagem do falcão Hórus como "alma" 5 . Ou, propondo o título "Fugir da imprudência", comenta: "Se querem indicar " rei que foge da loucura e da imprudência', pintam um elefante e um carneiro. Pois aquele, ao ver o carneiro, foge" (Horapolo 401).

Nos séculos XV, XVI e XVII, a leitura do livro reforçou a idéia de que os hieróglifos eram uma figuração enigmática ou alegoria fechada ou quase fechada. Como Horapolo faz definições do que então se acreditou ser uma imagem pictórica (não se sabia que os hieróglifos combinam pictogramas com signos fonéticos), os comentários de Hieroglyphica sugeriam a autores de emblemas e divisas a possibilidade de figurar visualmente os lugarescomuns do epigrama e do mote. O egiptólogo Claude François Brunon, lembrado por José Pascual Buxó, ocupou-se da interpretação dos hieróglifos do Hieroglyphica, demonstrando que substitui um código de notação de valores fonéticos, que utiliza imagens muito simples com valor puramente funcional ou diferencial, por um sistema de correspondências simbólicas que, em princípio, é alheio à verdadeira pictografia egípcia. Buxó lembra o hieróglifo 47, do livro I de Hieroglyphica. Nele se lê que, para denotar o "ouvido", os egípcios figuravam uma "orelha de vaca", o que é verdadeiro, mas somente quando a imagem de "orelha de vaca" é elemento do significante hieroglífico da noção verbalizada como "escutar": $s d m$. Por outras palavras, Horapolo faz uma interpretação simbólica de imagens que na pictografia

\footnotetext{
Sobre a interpretação de hieróglifos feita nos séculos XV e XVI, José Pascual Buxó escreve: "La ignorancia del texto verbal al que el jeroglífico sirve de expresión ideográfica vuelve misteriosos los contenidos conceptuales recluidos en la agrupación o secuencia de las imágenes de cuyo carácter fragmentario podría ya inferirse que cumplen la mera función de interpretantes intersemióticos; por el contrario, quien posea las claves de los correlatos que han de establecerse entre imágenes expresas y palabras tácitas y logre, en consecuencia, desentrañar el mensaje recluido en cada uno de esos enunciados de aspecto críptico, podría asumir ingenuamente que tal clase de signos (los jeroglíficos) forman parte de un lenguaje universal que se funda en una pretendida conexión natural (es decir, no arbitraria) entre determinados objetos y ciertos contenidos de índole sapiencial" (Cf. Buxó 43).
} 
egípcia representavam componentes fônicos de signos verbais, não a totalidade do referente e da referência figurados nelas (Buxó 43-44).

O texto grego de Horapolo circulou em cópias manuscritas até 1505, quando Aldo Manúcio o editou em Veneza. Nas muitas edições posteriores, foram adicionadas imagens e novas definições e comentários em latim e em línguas vulgares, o francês inicialmente. Desde sua descoberta, o texto foi lido como ars inveniendi ou compêndio de topoi, loci ou lugares-comuns da invenção poética, oratória e artística; e também como arte de lugares da elocução, tropos e figuras, extraídos dele como ornatos de sentido metafórico e alegórico e aplicados a discursos e a imagens pictóricas e plásticas. Na segunda metade do século $\mathrm{XV}$, a interpretação platônico-esotérica dos hieróglifos repetiu a interpretação de Horapolo, sendo posta em circulação pelos florentinos da Academia de Careggi, patrocinada pelos Médici em Fiesole. Marsilio Ficino, Pico della Mirandola, Cristoforo Landino e Angelo Poliziano, principalmente, então estabelecem concordâncias analógicas entre textos e objetos gregos, romanos e orientais, interpretando-os como hieróglifos, alegoricamente.

Seu método de interpretação alegórica unifica os mistérios pagãos e a revelação cristã numa genealogia ideal que fazem remontar a um mesmo significado místico, o destino da alma humana que retorna ao mundo das essências. Segundo a interpretação, esse significado aparece figurado nas formas sensíveis, naturais e artificiais, do mundo; os intérpretes reduzem a multiplicidade delas à unidade ideal, que expressam numa formulação alegórica. A alegoria figura a diferença entre o visível e o legível em signos esotéricos também visíveis e legíveis, mas quase sempre enigmáticos porque significam conhecimentos ocultos e transcendentes. Pressupõe-se plotinianamente, em cada caso, que as "coisas elevadas" estão para além de qualquer conceituação intelectual; assim, a interpretação aponta para o inefável sublime do Um epékeina tes ousías, "para além da presença".

A interpretação hipervaloriza o hieróglifo egípcio, postulando que a percepção da simultaneidade dos seus elementos é figura alegórica da contemplação extática das essências eternas pela alma reminiscente. A percepção visual da pictografia hieroglífica não é, evidentemente, linear ou sucessiva, como na leitura da escrita alfabética, e os platônicos florentinos pressupuseram com o Plotino da $V$ Enéada que os sacerdotes egípcios recorriam a hieróglifos, quando queriam significar as coisas divinas, sem usar letras seqüenciais, mas figuras inteiras de plantas ou animais, porque Deus tem um conhecimento que não é pensamento complexo, discursivo ou linear, mas forma simples e direta. Em vários lugares, Ficino afirma que a figuração humana do tempo 
é móvel e múltipla, pois ele se escoa enquanto os homens também passam, ligando as coisas linearmente, com começo, meio e fim. O tempo produz uma infinidade delas enquanto as destrói uma a uma. Para dizer tudo o que foi dito nos dois períodos anteriores, os egípcios teriam usado uma única imagem, a serpente alada que prende a cauda com a boca. Segundo a interpretação, os hieróglifos figuram coisas sagradas e secretas, como linguagem cifrada em que os prisci theologi, os antigos sábios, ocultaram do povo os mistérios da religião.

Na edição de 1531 de Emblemata, o epigrama e a imagem pictórica são formas metafóricas ou alegóricas emparelhadas que figuram a mesma noção ou conceito com certa redundância, ao passo que nas edições do Hieroglyphica a imagem ilustra o comentário feito sobre ela. Já no século XVI, foi proposto que o fato de a imagem pictórica do emblema ser chamada de corpo e o epigrama de alma corresponde à divisão do homem em corpo e alma e do mundo em terra e céu. Em 1594, Tasso afirma, comentando a afirmação de Paolo Giovio de que na empresa o discurso é "alma do corpo":

A alma é infinita e divina, o corpo caduco e terminado; entre ela e o corpo, portanto, não pode haver proporção; e se o mote é quase alma da empresa e participa da divindade e da imortalidade do poeta, não pode haver nenhuma proporção com a figura, mas a proporção se considera entre as partes do corpo (Tasso, ed. cit. 21).

Essa correspondência alegórica das partes do emblema com o corpo e a alma humanos também é pressuposta no "Trattato degli emblemi", onde Tesauro define o emblema como chave universal do sentido das coisas que, sendo condensado alegoricamente na alma e no corpo, dá-se ao entendimento do leitor-espectador como relação especular das partes que figura o espelhamento universal de inteligível/sensível que nas obras é operado por semelhança e analogia.

Tratando do termo grego "emblema", Tesauro afirma que os romanos o usavam para nomear um mosaico feito de esmalte e pedrinhas justapostas; também podia significar diversas espécies de ornamentos de ouro, prata e esmalte aplicados em vasos, colunas, frisos, arcos de triunfo, aparatos festivos, móveis e roupas (Tesauro, "Trattato degli emblemi" 693). Lembrando que Cícero chama de emblemata as decorações dos vasos que Verres roubou na Sicília, Tesauro retoma a etimologia de Rengifo, tratadista do século XVI, autor de uma Arte Poética Española, afirmando que o termo deriva do verbo grego emballein, "encaixar", como na etimologia semelhante proposta por 
Guillaume Budé, que também o relaciona a emblesthai, "inserir em, inserir sobre":

O termo Emblema nomeia uma obra de mosaico feita de pequenos quadrados encaixáveis. O Emblema entre os Antigos também eram ornamentos gravados sobre vasos de ouro, prata e esmalte destacáveis livremente: técnica desconhecida hoje, pelo que sei (Cit. por Pierre Laurens in Alciat, ed. cit. 17-18).

Desse modo, o termo inicialmente teria significado um encaixe de vários tipos de ornatos pictóricos e plásticos -no caso de textos, ornatos verbais- aplicados para acompanhar outras coisas. Os ornatos eram translações, literalmente, no sentido da "transferência" significada no termo "metáfora": figuravam coisas, como uma tocha acesa, para significar outras, podendo por isso ser isolados dos objetos a que se aplicavam como repertórios de res pictae ou elementos úteis para compor imagens. Rengifo diz que, na composição de emblemas, as figuras são extraídas dos próprios efeitos que se pretende figurar: a imagem da Tocha incendiada, que fica mais acesa quando é inclinada, significa "humildade", dando a entender que a virtude mais se fortalece quanto mais se humilha. Invertida, faz a cera apagar o fogo, significando "leviandade". De modo análogo, a imagem da "mosca", em emblemas e na pintura do século XVII significa apenas "mosca" pousada numa fruto de um bodegón ou "natureza morta"; pintada como elemento de uma composição do gênero vanitas, significa "decomposição" e "morte"; e, usada sozinha, por exemplo numa divisa, num emblema ou numa inscrição irônica que se envia para alguém, significa "falta de vergonha".

Os exemplos indicam algo fundamental para entender o gênero do emblema segundo os preceitos do ut pictura poesis: as palavras do epigrama significam o espaço, mas não são capazes de figurá-lo espacialmente. $\mathrm{O}$ significante "triângulo" não é triangular, diferentemente da imagem pintada de um triângulo como res picta que o figura no espaço e que, por convenção, significa ou simboliza metaforicamente o conceito de outra coisa, como a "Santíssima Trindade" significada por palavras. Assim, deve-se lembrar que o corpo (a imagem) e a alma (o discurso) são relacionados porque figuram os mesmos lugares-comuns por meios diferentes, verbais e pictóricos. O todo da imagem pictórica do corpo do emblema é composto como combinação de imagens menores ou parciais, que figuram "coisas significantes", como a mosca, que, por convenção metafórica, simbolizam as significações dos lugares-comuns também figuradas metaforicamente no discurso. Para ler a 
imagem e ver o discurso, o leitor deve reconhecê-las, relacionando corpo e alma de modo eficaz, ou seja, reproduzindo as operações da enunciação do texto e da composição da imagem, para a compreensão do efeito do conjunto. No caso, as res pictae constituem o que Cesare Ripa propõe como produtos da iconologia. Gombrich as chamou de icones symbolicae, imagens simbólicas; e Panofsky as propôs como objeto da iconografia. O corpo do Emblema LXXI de Alciato, Invidia, Inveja, é exemplar. É composto pela imagem de uma mulher esquálida, de seios murchos e caídos, cabelos desgrenhados e olhar furioso, que se apóia numa vara para andar enquanto come cobras cujas caudas se agitam no ar. O desenho das cobras que lhe saem da boca representa os répteis; simultaneamente, por convenção, a imagem das cobras sendo engolidas significa "coisa venenosa que corrói o coração do invejoso". Logo, se as palavras do epigrama significam, as coisas desenhadas da imagem são significadas- ou, dizendo melhor, recebem significação: Verba significant, res significantur, "As palavras significam, as coisas são significadas", diz Alciato (De verborum significatione libri quatuor, 1530, cit. por Buxó 43 e 53), afirmando que algumas vezes também as coisas significam, como ocorre nas res pictae dos hieróglifos de Horapolo.

O livro de emblemas Príncipe Perfeito, de 1790, é produzido com os mesmos pressupostos e procedimentos. Veja-se o Emblema IV: o mote latino Reges Deus habet quase pilas, "Deus governa os reis como bolas", encima o corpo que figura, em primeiro plano, um terreno onde três bolas tombam, arremessadas do alto por uma mão direita espalmada entre nuvens. As "coisas pintadas", bolas arremessadas e mão que sai de nuvens, metaforizam outras, "governo dos reis" e "Providência divina". Quanto à alma, é um epigrama de quatro versos em latim, onde se lê que a força divina joga, lançando a bola do alto, que salta, rola e cai. Segue-se o conselho ao Príncipe: deve temer os preceitos do Alto, pois é como uma bola na mão de Deus, que joga com ele (Solórzano Pereira, Príncipe Perfeito ed. cit. 14-15).

A consideração das relações que corpo e alma estabelecem no emblema deve, assim, pressupor o regulamento retórico das relações de pintura/ poesia. Nos tratados e obras desse tempo, elas são retoricamente reguladas como circularidade em que poetas imitam pintores que fornecem a poetas tópicas que são imitadas por emblemistas imitados por poetas e pintores. Por exemplo, por Sor Juana Inés de La Cruz, que evidencia que a composição do soneto transcrito adiante pressupõe a relação de poesia e pintura como $u t$ pictura poesis. O soneto é emulação de tópicas do retrato epidítico imitadas por Góngora num soneto de 1583, "Mientras por competir com tu cabello", 
cujo verso final, "en tierra, en polvo, en humo, en sombra, en nada", o verso final do poema de Sor Juana imita:

Éste, que ves, engaño colorido, que del arte ostentando los primores, con falsos silogismos de colores es cauteloso engaño del sentido; este, en quien la lisonja ha pretendido excusar de los años los horrores, y venciendo del tiempo los rigores triunfar de la vejez y del olvido, es un vano artificio del cuidado, es una flor al viento delicada, es un resguardo inútil para el hado:

es una necia diligencia errada, es un afán caduco y, bien mirado, es cadáver, es polvo, es sombra, es nada

("Procura desmentir los elogios a un retrato de la poetisa").

De modo análogo, Rubens evidencia a relação como ut poesis pictura em uma carta para o pintor holandês Justus Sustermans, que lhe pedia explicação sobre Os Horrores da Guerra, pintado entre 1637 e 1638. Rubens informa que imitou a poesia homérica; a tela não deve ser apenas vista, mas lida e interpretada como alegoria:

A figura principal é Marte que, deixando aberto o Templo de Jano (era um costume romano deixar o Templo de Jano fechado em tempos de paz) avança com seu escudo e sua espada manchada de sangue, arrasando as nações com grande devastação e dando pouca atenção a Vênus, sua amante que, acompanhada de seus Cupidos e amores, tenta pará-lo com carícias e abraços. Do outro lado, Marte é acompanhado da Fúria Alecto, segurando uma tocha na mão. Perto aparecem monstros, representando a Peste e a Fome, companheiras inseparáveis da guerra; no chão jaz uma mulher com uma lira quebrada, significando a harmonia, que é incompatível com a discórdia da guerra; também há uma Mãe com seu filho nos braços, denotando que a fecundidade, a geração e a caridade estão pisoteadas pela guerra, que corrompe e destrói todas as coisas. Ainda há um arquiteto, que jaz com seus instrumentos na mão para demonstrar que o que é construído para a comodidade e ornamento da Cidade está reduzido a ruínas e 
subvertido pela violência das armas. Eu acredito que, se me lembro bem, você também achará no chão, entre os pés de Marte, um livro e alguns desenhos sobre papel para demonstrar que ele pisoteia as letras e as outras artes. Também existe, acredito, um feixe de flechas com a corda que as amarra desatada, porque quando atadas elas são o emblema da Concórdia; e eu também pintei, ao lado delas, o caduceu e a oliveira, o símbolo da paz. A Matrona lúgubre vestida de preto e com o véu rasgado, despojada de suas jóias e de qualquer ornamento, é a infeliz Europa, afligida por tantos anos de rapina, ultraje e miséria que, por serem tão nocivos para todos, não precisam ser especificados. $\mathrm{O}$ atributo de Europa é aquele globo segurado por um menino (putto) e encimado por um elmo que significa o orbe cristão. Isso é tudo que lhe posso dizer (Rubens, "Carta a Justus Sustermans", cit. por Gombrich 123).

Como os poetas e os tratadistas de emblemática do século XVII, Rubens não diz que a pintura é a poesia ou vice-versa, mas que ambas imitam os mesmos lugares-comuns em artes e substâncias diversas. No relato sobre a festa do Triunfo Eucarístico, realizada em Vila Rica em 1733, publicado em 1734 por Simão Ferreira Machado, encontra-se o mesmo pressuposto mimético da carta de Rubens e do poema de Sor Juana. Na descrição de Marte, por exemplo:

...Vinha Marte em distância de dois passos: armava-lhe a cabeça um capacete de prata de lavores de pedraria, rematado num precioso cocar de plumas brancas, e encarnadas; vestia de seda branca de prata; o peito em campo da mesma seda, bordado de ouro (...) na mão direita empunhava uma espada nua de guarnições de prata, e lavores de ouro; e na esquerda um escudo de prata... (Machado,v. III, t. I-II: 212).

A comparação do texto de Simão Ferreira Machado com outros que narramdescrevem festejos coloniais evidenciaria a mesma coisa, ou seja, a mesma unidade de procedimento pelo qual a escrita é feita como imitação de imagens da pintura e de almas e corpos de emblemas, assim como Rubens pinta imitando tópicas da poesia e Sor Juana escreve imitando tópicas da pintura de retratos. Em todos os casos, a poesia mostra, como se fosse imagem pictórica, e a pintura significa, como se fosse discurso poético. Em todos os casos, a representação exterior do conceito imita as articulações do pensamento, que são convenientes com as articulações das coisas, as res da inventio. Robert Klein demonstrou que a poesia, a prosa, a emblemática e mais artes dos séculos XVI e XVII pressupõem uma lógica da imagem, definida como imagem 
simultaneamente dialética e retórica, que funciona como argumento sensível ou visualização do conceito. Hoje, o pictórico e o plástico são irredutíveis ao discurso, que fala sobre o espaço, não $o$ espaço; nos livros de emblemas e empresas, há continuidade entre a poesia, a prosa, a pintura e a escultura, pois têm o mesmo fundamento mimético. O mesmo topos pode ser figurado em artes diferentes, pois o que importa é o modo da imitação segundo os gêneros: a pintura de história põe em cena topoi ou lugares encontrados no discurso da história e da poesia; a poesia épica e o gênero histórico põem em cena os lugares calculando os efeitos visualizantes do discurso como a enargeia ou "vividez" proposta por Aristóteles e traduzida pelos latinos como evidentia. Assim, no ato da invenção do emblema, o autor lembra os lugarescomuns de um dos seus três gêneros - judicial, deliberativo, demonstrativo - para pintá-los com palavras. Os processos dialético-retóricos que definem e analisam os lugares da inventio e os ornatos da elocutio não fundamentam nenhuma "estética", que pressupõe a psicologia e tantas vezes, como hoje, a psicanálise com que as obras são deitadas no divã para que os intérpretes façam livres-associações. Os processos dialético-retóricos do engenho do autor fundamentam uma técnica, como dizia Klein, que é um saber-fazer ou ciência de preceitos, procedimentos e efeitos verossímeis e decorosos, como técnica específica da racionalidade não-psicológica da mímesis aristotélica (Klein, "La théorie de l'expression figurée dans les traités italiens sur les 'imprese', 1555-1612").

Os nomes antigos que eram interpretados com o termo genérico "emblema" e que hoje ficaram estranhos -argumenta, ornamenta, parerga, anaglypta, chrysendeta, dedalmata - referem-se apenas a ornamentos, diferentemente da definição do termo "emblema" feita por Tesauro como nome do gênero inventado por Alciato com a colaboração não prevista de Steyner:

Um Símbolo Popular; composto de Figura e Palavras, significante como Argumento algum Documento referente à vida humana: e por isso, exposto como friso e ornamento nos Quadros, nas Salas, nos Aparatos, nas Academias, ou impresso nos livros com Imagens e explicações para o público ensinamento do Povo (Tesauro 694).

Como na edição de 1531 dos Emblemata, a definição contempla as duas partes principais do emblema: Palavras (discurso, epigrama, alma) e Figura (imagem pictórica, corpo), que significam algo como "metáfora simbólica". No caso, tanto alma quanto corpo são "metáforas simbólicas" porque substituem uma "coisa" ( um lugar-comum retórico ou poético) pela representação dela 
por meio de palavras e imagens de coisas para significar convencionalmente outras coisas, como ocorre no uso da palavra "diamante" e da imagem do mesmo como símbolo de "homem forte"; da cegonha, como símbolo de "vigilância"; da lança, para significar "liberdade" etc. No emblema mostra-se uma coisa e entende-se outra, como a metáfora, que mostra um leão dando a entender "Aquiles". A relação metafórica, que se estabelece entre a imagem e o conceito "arquétipo" no corpo e palavra e o mesmo conceito "arquétipo" na alma, é a de um entimema ou silogismo retórico que propõe uma conclusão baseada na semelhança de dois termos: se o leão é forte e se Aquiles é forte, pode-se pensar por comparação que "Aquiles é como um leão" e dizer por metáfora que "Aquiles é um leão". Do mesmo modo, se a cobra é venenosa e mata os seres vivos que morde e se o vício da inveja é destrutivo e corrói o coração do invejoso, usa-se a imagem "mulher esquálida engolindo cobras" para pintar a inveja.

Nos séculos XVI e XVII, esse modo de figuração alegórica é consensual e repete-se nos tratados que muitas vezes alimentam os exemplos com emblemas. Quando define as operações metafóricas do emblema, Tesauro rediz o que diz Baltasar Gracián no primeiro capítulo de Agudeza y arte de Ingenio ao definir o conceito engenhoso como a metáfora nascida de um ato do entendimento que exprime a correspondência achada entre coisas preferencialmente distantes (Agudeza y arte de ingenio, I). Exemplificando, Gracián cita o Emblema CXII dos Emblemata: depois de ser picado pelas abelhas de um enxame que golpeou com sua flecha, Cupido foge, perguntando a Vênus como um animal tão pequeno pode causar tanta dor. Vênus ri e lhe diz que ele, Cupido, é idêntico às abelhas. No caso, a metáfora é obtida pela proporção A:B :: C:D: "abelha: mel (dor das picadas) :: Amor: doçura (prazer; sofrimento)". A divisa do rei francês Luís XII, composta pela imagem de um porco-espinho e pela inscrição latina Eminus et cominus, "De perto e de longe", é construída do mesmo modo, como entimema ou silogismo retórico que adverte: o ouriço tem espinhos que ferem inimigos de perto e de longe; Luís XII tem armas como os espinhos do ouriço; logo, Luís XII ... etc.

Quando fala de Argumento, Tesauro entende o topos, locus ou lugar-comum como "sede dos argumentos" da invenção de um "documento" de interesse

6 No século XVII, "conceito arquétipo" nomeia o conceito na mente, antes da sua figuração exterior por signos. 
geral. E, falando de "Povo", não se refere à plebe, apenas, mas também a engenhos medianos cujo conhecimento das letras antigas é medíocre. $\mathrm{O}$ latim é entendido por todas as nações; mas, para quem não o compreende, o epigrama latino do emblema é totalmente supérfluo. Assim, como o emblema é gênero popular, o epigrama deve ser escrito em língua vulgar, como também se pode fazer nas empresas (Tesauro 695). Nos emblemas, a alma evidencia para o leitor-espectador a relação que estabelece com o corpo para figurar significações filosófico-morais. Quanto ao corpo, remete o leitor-espectador a um texto implícito, mimetizado convencionalmente no desenho da imagem. Fazendo a relação alma/corpo, o leitor-espectador avalia a imagem e o discurso; para isso, também lembra significações paradigmáticas. Não-figuradas diretamente no emblema nele, o leitor-espectador as acha em artes da memória (Buxó 35-36).

Nos incontáveis livros de emblemas feitos nos séculos XVI e XVII, imitam-se muitas significações textuais e pictóricas anteriores à voga do gênero iniciada pela segunda edição dos Emblemata. É o caso do romance alegórico Hypnerotomachia Poliphili, O Sonho de Polifilo, de Francesco Colonna (1433-1527), dominicano do convento de San Giovanni e Paolo de Veneza. Publicado por Aldo Manúcio em 1499, o texto narra a viagem iniciática da alma do personagem Polifilo pela "floresta escura" da vida sensível em busca do verdadeiro amor, Polia. Depois de atravessar muitas e muitas alegorias, Polifilo está iniciado nos mistérios do amor e casa-se com a dama, indo viver com ela na ilha de Chipre, consagrada a Vênus. No percurso da iniciação, o herói encontra monumentos carregados de inscrições, figuras enigmáticas e hieróglifos, que o narrador descreve e interpreta. Como Steynen, Aldo Manúcio acrescentou imagens de xilogravuras ao texto. Colonna chama as imagens referidas pelo narrador de emblematura, também usando o adjetivo emblemático para qualificá-las. Integrando-se funcionalmente na história narrada, os lugares-comuns, os argumentos e acidentes das imagens fornecem res pictae para a composição de epigramas e imagens pictóricas de novos emblemas e empresas. No Sonho de Polifilo, a imagem de um golfinho que se enrola numa âncora, que tinha sido gravada numa moeda do imperador romano Tito, é comentada em um texto italiano acompanhado de uma sentença em latim. O texto italiano diz: "Do lado esquerdo, e propriamente oposto, havia um outro semelhante, mas era de pedra serpentina também com uma escultura de hieróglifos, um Círculo e uma Âncora, sobre a qual estava enrodilhado um Golfinho e eu os interpretei semelhantemente desta maneira". Segue a interpretação na forma de sentença e lema: Semper festina 
tarde, "Apressa-te sempre devagar", lema de Augusto referido por Suetônio na vida de Augusto em seu De vita Caesarum, II, 25,4. Aldo Manúcio, citado por Alciato na carta a Francesco Calvi, adotou a imagem do golfinho enrolado na âncora como empresa nos livros que editou.

Em 1556, Pierio Valeriano Bolzani publicou seu Hieroglyphica. Retomando Horapolo, amplia o repertório de imagens com comentários que as explicam como figurações hieroglíficas ou alegóricas de virtudes e vícios. O livro funciona como exposição comentada de imagens e discursos, também passando a ser usado como arte de lugares-comuns da invenção e da elocução de pintores, escultores, poetas, gravadores etc. Valeriano elenca significações alegóricas para usos de imagens de animais muitas vezes extraídas de Oneirocritica (Interpretação dos Sonhos), de Artemidoro de Éfeso: a imagem da mosca, como "falta de vergonha", porque sempre volta quando enxotada; a da perdiz, interpretada como no texto de Horapolo: "Para denotar o pecado contra a natureza, eles (os egípcios) pintavam dois machos de perdizes, os quais, privados de fêmeas, abusam um do outro" (Valeriano, Les hieroglyphiques). Assim como a perdiz significa "luxúria", a imagem do elefante sempre grávido, que Alciato refere na carta a Francesco Calvi, significa "memória" e "prudência", como se vê na escultura do elefante que leva um obelisco egípcio nas costas feita e colocada por Bernini na Piazza della Minerva, em Roma.

Lembre-se ainda o proêmio de Iconologia ou Descrição das imagens universais escavadas da Antigüidade e de outros lugares por Cesare Ripa, perusiano. Obra não menos útil que necessária a Poetas, Pintores \& Escultores, para representar as virtudes, vícios, afetos e paixões humanas (1593). Ripa afirma que vai analisar "imagens que são feitas para significar coisa diferente da que é dada a ver". Como sempre, são retóricas as categorias que especificam os preceitos das relações metafóricas da imagem pictórica e o lugar-comum de um discurso imitado nela. As categorias prescrevem a adequação da imagem e da palavra a verdades conhecidas para produzir o efeito de verossimilhança e de decoro: para coisas do conhecimento, imagens e palavras de coisas elevadas; para coisas moralmente dignas, imagens e palavras de coisas graves; para coisas vis, imagens e palavras de coisas deformadas, etc.

Ripa define iconologia como lógica das imagens (ragionamenti d'imagini) duplamente articulada como formare e dicchiarare: formar, técnica inventiva, e declarar, técnica interpretativa (Ripa, Iconologia). Quando propõe a imagem pictórica como "definição ilustrada", Ripa pensa aristotelicamente, pressupondo 
que não há pensamento sem imagem. Assim, os conceitos a serem figurados no discurso e na imagem do emblema são definições porque são conclusões de entimemas ou silogismos retóricos; e definições ilustradas porque sua forma "arquétipa", ou forma antes de ser figurada exteriormente, é imagem vista pelo olhar intelectual do juízo. A forma-matriz da "definição ilustrada" é uma imagem, uma metáfora "arquétipa", como matéria a partir da qual as duas figurações por signos exteriores, o corpo e a alma do emblema, são produzidas associativamente, como substituição e condensação de imagens pictóricas e verbais fornecidas à imaginação dos autores pela memória dos usos autorizados do costume (consuetudo). Com esse pressuposto, Ripa explica que a definição do conceito é formulada com poucos termos e que a imitação dela pela pintura deve produzir uma imagem simples ou sintética. Para que a imagem pintada se assemelhe à definição do conceito, deve ser figurada segundo as diferenças específicas e acidentes da coisa definida. As diferenças e os acidentes que caracterizam a coisa figurada na imagem são classificados em elencos de lugares, que recebem uma forma distinta e clara, principalmente os acidentes da fisionomia e do corpo humano, que convencionalmente metaforizam o caráter e a paixão principais a que se adapta a forma construída pelo desenho.

Desta maneira, quando o autor do emblema já definiu mentalmente as causas, os atributos essenciais e os acidentes de uma coisa que pretende figurar, acha uma semelhança com ela nos elencos memorizados de imagens desenhadas de coisas para escolher a mais conveniente e figurar convencionalmente a imagem mental da definição no corpo do emblema. No caso, a semelhança mais louvável deve ser a da analogia de proporção- A:B :: C:D. Se o pintor das imagens do emblema quer figurar o conceito de /Força/, pinta uma Coluna, considerando a analogia, porque a coluna suporta fisicamente todo o peso do edifício, sem vacilar. Verbalmente, quando se compõe o epigrama, pode-se dizer com metáfora que o "homem forte", que moralmente supera todas as dificuldades, é uma "coluna". Da mesma maneira, fala-se que a Espada e o Escudo são semelhantes à Retórica, pressupondo-se que, assim como o soldado ataca com a espada e se defende com o escudo, o orador combate opiniões contrárias e sustenta opiniões favoráveis com argumentos. Assim, pode-se inventar a imagem da Retórica como mulher armada de espada e escudo. Do mesmo modo, pinta-se a Beleza com a cabeça oculta entre nuvens, pois a imagem da nuvem cobrindo a cabeça de um corpo feminino significa que não existe nada que mais dificilmente se possa representar com a linguagem mortal e que menos se possa conhecer com o intelecto humano 
que a Beleza, pois, nas coisas criadas, ela não é outra coisa, em sentido metafórico, que um esplendor emanado da luz invisível do rosto de Deus, como dizem os platônicos.

Retomando Pimandro, o primeiro livro do Corpus hermeticum de Hermes Trismegisto, Ripa propõe que as imagens pictóricas compostas no emblema com as proporções que prescreve figuram coisas para metaforizar lugarescomuns divinos e humanos. No segundo caso, lugares humanos, as imagens pressupõem o conceito, definido como "tudo quanto possa ser significado por palavras e que se divide em duas partes". Uma das partes do conceito consiste em afirmar ou negar coisas a respeito de outras. É nela que se fundamenta a arte dos autores de divisas, que afirmam ou negam um único conceito por meio de um pequeno número de palavras e imagens. Essa parte também é o fundamento da arte dos emblemas, com a diferença de que o emblema afirma ou nega conceitos mais desenvolvidos, com maior número de palavras e imagens.

A segunda parte do conceito -a que não afirma nem nega- fundamenta a invenção de imagens que figuram definições de vícios e virtudes, sem afirmar ou negar. No caso, pictoricamente, as definições devem ser expressas pela figura humana porque, assim como a definição é a medida do definido, o homem é a medida de todas as coisas. Com tal proporção, a figura humana é aplicada como medida acidental de qualidades definidas como paixões da alma humana. Desta maneira, propondo "o homem" como modelo das imagens pictóricas do emblema, Ripa afirma que só se obtêm boas imagens quando o corpo humano da imagem pictórica evidencia a relação de homologia com o gênero da definição verbal. Para figurar Melancolia, por exemplo, compõe-se uma imagem humana que tem o rosto seco e macilento, cabeços eriçados, barba hirsuta e carnes enrugadas, pois tais aspectos tristes e envelhecidos são aptos para estabelecer convencionalmente a homologia com a qualidade que caracteriza o humor na definição de Melancolia, o humor negro da contemplação triste, aquém da contemplação superior. Em todos os casos, o conceito inicial, que a invenção acha em elencos da memória, é o phantasma ou a "imagem arquétipa" concebida intelectualmente pelo autor antes de figurá-la com signos exteriores.

Em Iconologia, Ripa descreve os tipos humanos da alma por meio da notatio, do Ad Herennium e outros retores latinos: a notatio é a perífrase verbal breve, como a do epigrama de Marcial- "Quinto ama Taís. Qual Taís? Taís, a caolha. Taís não tem um olho; ele, os dois" - que descreve o caráter da personificação alegórica de conceitos, como "Fraude", "Tempo", "Fortuna", 
"Primavera", "Juventude" etc. Para compor as imagens dos corpos humanos, recorre ao Physiognomonia, de Giovanni Della Porta. Pressupondo a notatio, o desenho compara os traços do rosto humano com traços de animais para efetuar deformações da fisionomia e do corpo humano adequadas à paixão que especifica o éthos ou o caráter do personagem.

Nos tratados de emblemas e empresas dos séculos XVI e XVII, costumase afirmar que a semelhança mais adequada à composição das imagens do corpo e dos discursos da alma é a de proporção. Consideram-se duas espécies da semelhança: a semelhança chamada unívoca, que se estabelece entre duas coisas que participam numa mesma forma e a semelhança estabelecida entre duas coisas que não têm uma forma comum, mas duas proporcionalmente semelhantes. Assim, quando um emblemista quer figurar o conceito de Ocasião ou Fortuna, pinta uma mulher nua, calva na nuca, com uma mecha de cabelos na testa, uma navalha na mão direita e pés alados que pousam sobre o eixo de uma roda deitada no chão ou no mar, para significar "o instante de tempo capturado que domina todas as coisas", como no Emblema CXXI de Alciato, In Occasionem, "Sobre a Ocasião". As partes e as posições do corpo são ícones simbólicos ou metafóricos; assim, o desenho da posição "em pé" significa "dá voltas continuamente"; dos pés alados, "arrastada pela mais leve brisa"; da navalha na mão direita, "mais aguda que toda agudeza"; da mecha de cabelos na testa, "deve ser agarrada de frente quando se apresenta"; da calvície da nuca, "se alguém deixa escapar a ocasião com seus pés alados, não pode mais segurá-la". Desta maneira, pressupõe-se que, assim como pés alados voam, a ocasião passa velozmente. Duas coisas de gêneros diferentes, "pé alado" e "ocasião", são aproximadas por meio da semelhança estabelecida com uma terceira, "velocidade", outro gênero.

No caso da segunda forma de semelhança, propõe-se, por exemplo, a semelhança do fogo com o amor, pois o fogo é fisicamente impetuoso e o amor o é moralmente; ou a semelhança da coleira com a lei, pois a coleira reprime e defende o cachorro, assim como a lei reprime e defende o cidadão etc. Dessas duas espécies de semelhanças nascem duas espécies de metáforas. A primeira transporta o conceito de espécie a espécie, como quando se diz "metal" por "ferro"; "neve" para significar os lírios que nascem no inverno; "alabastro" por mãos brancas. Ou quando se fala que César foi "um Alexandre" e que tal soldado é "um César" etc. Com tais metáforas, também é possível compor símbolos, como fizeram os espartanos na mensagem que enviaram a Filipe da Macedônia, que os ameaçava: Dionysius Corinthii, "Dionísio em Corinto". Lembravam-lhe que Dionísio de Siracusa tinha sido deposto por 
causa da soberba tirânica, transformando-se num andarilho em Corinto (Tesauro 53). Aristóteles diz que a maior parte dos provérbios são transferências de semelhante a semelhante, como quando se diz "Quem com ferro fere, com ferro será ferido", para significar que "a violência causa violências". No caso, essa é a semelhança com que os corpos de emblemas são compostos. Usando-se a imagem de um homem que anda com uma lanterna acesa num dia de sol, o espectador do emblema entende que "Diógenes procura um homem com sua lanterna" significa alegoricamente "O Príncipe deve procurar bons conselheiros"7. Com a imagem de um homem musculoso que ergue outro do chão, apertando-lhe o peito com os braços contra o próprio peito para sufocá-lo, entende-se "Hércules sufoca Anteu" para significar outra coisa. Valeriano diz que Hércules é uma semelhança e um retrato da alma participada da razão e do espírito humano, enquanto Anteu é uma semelhança da matéria do corpo: o peito de Hércules é imagem da "sede da sabedoria e da prudência", que fazem perpétua guerra contra "os apetites e a vontade" simbolizados por Anteu (Valeriano 1, LIX: 783). Mas são as metáforas de proporção as preferidas dos autores de emblemas, pois aproximam duas coisas e dois conceitos distantes, pondo sob os olhos uma figura e propriedades de gênero diverso, mas sempre proporcionadas, como o porco-espinho e o rei, ainda que a comparação não seja lá muito decorosa, pois o porco-espinho não deixa de ser uma espécie de porco, como Tesauro diz maliciosamente.

Os autores de emblemas costumam definir o conceito produzido pelo juízo do leitor-espectador quando lê-vê o corpo e a alma do emblema como "nó" de idéia e imagem. A noção de "nó" designa a técnica e significa o efeito da relação metafórica estabelecida entre a imagem pictórica e o epigrama. Duas referências aristotélicas são fundamentais em sua definição como "nó": o Livro III da Retórica, sobre a elocução metafórica; o Livro III, do De anima, sobre o juízo silogístico. Como procedimento técnico, as metáforas emblemáticas fundem procedimentos dialéticos de definição e retóricos de ornamentação; como efeitos, são doutrinadas como figuração engenhosa,

\footnotetext{
A propósito da imagem de Diógenes citada por Tesauro, Maria Luisa Doglio lembra um emblema de G. de La Perrière, em La Morosophie, contenant cent emblemes moraux illustrez de cent tetrastiques latins reduitz em autant de quatrains françois. A Lyon, par M. Bonhomme, 1553, n. XXXI. Nele, sob o corpo (a imagem de Diógenes com a lanterna), lê-se "Diogenés jadis cherchoit un homme/Parmy les gens plus de mil et cinq cent:/Mais entre tous il n'apperceut en somme/Qu'hommes de peau et n'en veit un de sens'. Cf. Idea delle Perfette Imprese, ed. cit. 54.
} 
aguda, breve e sensível de afetos tidos como universais. Para a figuração metafórica do "nó", recorre-se a lugares-comuns retóricos e poéticos, que foram memorizados e armazenados em elencos, analisando-os dialeticamente por meio das 10 categorias aristotélicas: substância, qualidade, quantidade, tempo, lugar, situação, posição, ação, paixão, hábito.

Em Il Cannocchiale Aristotélico (1654), Tesauro propõe o uso do "índice categórico", as 10 categorias, para inventar definições ilustradas. Sob a categoria de substância, vem Deus, ainda que esteja acima de toda categoria: as divinas pessoas da Trindade; a Idéia; os deuses fabulosos. Os deuses celestes, aéreos, marinhos, terrenos, infernais; os heróis, homens deificados. Anjos e demônios. O céu e as estrelas. Os signos celestes e as constelações, ou imagens da oitava esfera. O Zodíaco e todos os círculos e esferas imaginários. Os quatro elementos, os vapores, que são fumos quentes, e as exalações, frios. O fogo, a esfera ígnea, os fogos subterrâneos. O ar e seus meteoros, estrelas cadentes, cometas, raios, ventos, neves, chuvas. A água e os mares, rios, fontes, lagos. A terra, campos, prados, desertos, montes, colinas, promontórios, vales, precipícios. Os corpos, mistos inanimados, pedras, mármores, gemas, metais, plantas, ervas, flores, árvores, arbustos, corais. Animais terrestres, feras, e aquáticos, e aéreos, pássaros, e os monstros. Homem, mulher, hermafrodita. Há também a substância artificial, ou as obras de toda arte: nas ciências, livros, penas, tintas; na matemática, globos, mapasmundi, compassos, esquadros. Na arquitetura, palácios, templos, tugúrios, torres, fortalezas. Na arte militar, armas, escudos, espadas, tambores, tubas, cornetas, bandeiras, troféus. Na pintura e na escultura, quadros, pincéis, cores, estátuas, escalpelos. Além da substância física, o engenho do autor também considera a substância metafísica, como o Gênero, a Espécie, a Diferença, o Próprio, o Acidente em geral: o nome, o cognome e noções semelhantes. Nos emblemas, as metáforas de acidentes são mais adequadas que as de substância, porque implicam relações mais convenientes para a metaforização visualizante própria da evidentia.

Sob a categoria de quantidade, o autor considera a quantidade do tamanho: pequeno, grande; longo, curto; a quantidade numérica: nenhum, um, dois etc., muitos, poucos; a quantidade de peso: leve, pesado; a quantidade de apreço: precioso, vil. E a quantidade em geral: medida, parte, todo: perfeito, imperfeito: finito, infinito, divisível, indivisível, proporcionado, desproporcionado, maior, menor, igual etc. Pela categoria qualidade, inventa imagens que pertencem à visão: visível, invisível, aparente; belo, disforme; claro, obscuro: branco, negro, púrpura etc. Ou que pertencem à audição: som, silêncio, harmônico, 
desarmônico. Ao olfato: suave, forte. Ao gosto: saboroso, insosso etc. Ao tato: quente, frio, seco, úmido, liso, áspero. Também as qualidades figurais: direito, torto, redondo, quadrado, agudo, obtuso etc. E o que Tesauro chama de qualidades exteriormente denominantes: fama, infâmia; honra, desonra, fortuna, infortúnio. Ou as qualidades internas naturais: são, doente, prazeroso, doloroso. Também existe a qualidade de paixões: alegria, tristeza, amor, ódio, esperança, medo. E qualidades intelectuais: sabedoria, ignorância, arte, inépcia. E, obviamente, qualidades morais: a virtude e a infinitude dos vícios.

A categoria relação dá conta do parentesco e da companhia, da amizade e simpatias, das inimizades e antipatias, dos semelhantes, dos contrários, dos opostos, do superior, do inferior e também das causas das coisas: causa eficiente e efeito; causa material e forma; causa final e privação, nomes, títulos, verdade e falsidade. Com as categorias de ação e paixão, o emblemista pensa em: potente, impotente; fácil, difícil; nocivo, inofensivo; útil, danoso etc. E em operações naturais: nutrir, produzir. Em operações políticas: reinar, julgar, guerrear, tiranizar. Em ações mecânicas: fazer, desfazer, cansaço, ócio, calma. Em ações cerimoniais: festivas, fúnebres, sagradas etc. Quanto à categoria situação, lembra-se de: alto, baixo, plano, jacente, pendente, cruzado, direito, esquerdo, médio, dentro, fora etc. E com a categoria tempo: momentâneo, durável, novo, velho, principiar, acabar. Quanto à categoria lugar: pleno, vazio. Movimento: veloz, lento, direito, oblíquo: de um lugar, por um lugar, perto de um lugar, em direção a um lugar etc. Quanto ao ter, ou à posse: rico, pobre; vestes, empresas, divisas, armas, ornamentos, instrumentos etc.

Tendo encontrado 10 definições de uma coisa e um conceito pela aplicação das 10 categorias, o autor do emblema seleciona palavras e imagens pictóricas que aplica à definição escolhida para compor a alma e o corpo, segundo a necessidade e a verossimilhança (Aristóteles, Poética 1451b), do caso que figura em ambos. Aqui a metáfora não o simples tropo de palavra que substitui o sentido próprio pelo figurado, pois ela está na base da invenção retórica como a definição ilustrada ou "imagem arquétipa" que os signos verbais e pictóricos figuram para o destinatário como efeito das operações do juízo e da versatilidade do autor. O decoro dialético-retórico que o juízo aplica à sua composição é aplaudido porque o efeito é engenhoso, sendo também elogiado como conveniência moral e política que emula o costume das autoridades da arte do emblema. A metáfora sempre pressupõe a proporção racional do silogismo, principalmente quando, da perspectiva aristotélica ortodoxa, seu efeito pode ser avaliado como incongruente ou sem medida. O engenho do bom emblemista é, porém, como o do bom poeta e bom pintor 
que, na formulação de Tesauro, produzem «inconveniências convenientes» ou "despropósitos propositais" ${ }^{8}$, perdendo o juízo muito ajuizadamente, pois demonstram racionalmente que a metáfora

Faz que o Leão se torne um Homem, \& a Águia uma Cidade. Põe uma Mulher sobre um Peixe \& fabrica uma Sereia como Símbolo do Adulador. Cola um busto de Cabra ao rabo de uma Serpente \& fabrica a Quimera como Hieróglifo da Loucura. Por isso entre os antigos Filósofos, alguns chamavam o Engenho de partícula da Mente Divina: \& outros o chamaram de presente mandado por Deus aos seus mais caros?.

Logo, a imagem pictórica e o epigrama compostos com essas proporções devem ser antes de tudo boas imagens reguladas por adequações verossímeis e decorosas da forma aos gêneros e às tópicas do emblema. Para fazer boas imagens, o autor deve adequá-las às partes essenciais do "perfeito emblema", como diz Tesauro, o tema, a figura e a inscrição. O tema é mote ou título que explicita a finalidade do emblema, como vituperar a avareza, louvar a gratidão, exortar à concórdia etc. $\mathrm{O}$ tema é expresso pelo título - por exemplo, o do Emblema XCIII de Alciato, In avaros (Sobre os avarentos). A forma da imagem pictórica sempre se inclui em um gênero, que determina os lugarescomuns e a elocução dela. Assim, o corpo do emblema pode ser composto por uma imagem histórica, como a do "habitante da Finlândia", do Emblema XLIV de Alciato, cuja referência é imitada do discurso de um historiador, Tácito. O habitante da Finlândia é um tipo tão pobre, tão desprovido de tudo, que nem a Fortuna lhe pode fazer mal. A imagem dele é a de um homem com uma pele jogada às costas que leva um arco, significando "segurança dos que levam consigo todos os seus bens". A imagem pode ser fabulosa, como a do Emblema LVI de Alciato, Faetonte despenhando-se do céu, que

"Né si può dire che questi pecchino contro l'arte quando sanno molto bene che lasciano il decoro ma lo vogliono lasciare; si come il pittore non erra contra l'arte quando a bello studio tratteggia un ceffo torto e stralunato come la statua di Serapide, avendo ogn'arte (eccetto la prudenza) questo privilegio, come dice Aristotele, di non peccar contro arte quando a posta pecca contro '1 suo fine". (Tesauro, Idea delle Perfette Imprese 112).

$9 \quad$... fa che il Leone divenga un'Huomo;\& l'Aquila una Città. Inesta una Femina sopra un Pesce; \& fabrica una Sirena per Simbolo dell'Adulatore. Accoppia un busto di Capra al deretano di un Serpe;\& forma la Chimera per Hieroglifico della Pazzia. Onde fra gli antiqui Filosofi, alcuni chiamarano l'Ingegno, Particella della Mente Divina: \& altri un regalo mandato da Iddio a 'suoi più cari. Tesauro, Il Cannocchiale Aristotelico, ed. cit, 82-83. 
imita o discurso de um mito e é usada para significar "repreensão moral dos temerários". A imagem natural recorre à figuração de coisas da Natureza, rochas, montes, rios, fontes, plantas, aves e animais etc. É o caso do Emblema XXX, de Alciato, em que filhotes de cegonha cuidam de uma ave envelhecida, significando "piedade filial e gratidão para com os benfeitores". Usam-se ainda imagens de coisas artificiais, caso da imagem do túmulo de Arquíloco, no Emblema LI de Alciato, significando "o maledicente". Finalmente, há as imagens quiméricas, como o golfinho enrolado na âncora da divisa de Augusto, significando "rapidez controlada". Quanto à inscrição, epigrama ou alma, deve ter as duas partes já referidas: a primeira é uma explicação da fábula ou história que se narra ou declara; a segunda aplica a história ou fábula ao que é significado no epigrama.

O tema, a inscrição e a figura são sempre adequados aos três genera dicendi que classificam os emblemas- judicial, deliberativo e demonstrativo. Como na oratória forense, o emblema judicial compõe-se de corpo e alma que condenam ou defendem algo já conhecido; logo, seu tempo de referência é o passado. O emblema deliberativo aconselha ou desaconselha determinada coisa ou ação, referindo-os ao futuro. Quanto ao emblema demonstrativo ou epidítico, usa-se para louvar as coisas honradas e vituperar as viciosas. O tempo da sua referência é o presente e a ele pertencem todos os emblemas doutrinais, que ensinam um conceito teológico, moral, filosófico ou natural.

Tanto no emblema quanto na empresa - (no século XVI, o termo italiano empresa passa a substituir o francês divisa)- deve-se usar o corpo humano para compor a imagem pictórica. Com uma diferença fundamental: na empresa (divisa), o corpo humano é pintado como sinédoque ou parte pelo todo; no emblema, como metáfora. Dizendo de outro modo: a empresa (divisa) só pode representar partes do corpo humano; no emblema, o corpo deve ser representado por inteiro. Ao mesmo tempo, ambos os gêneros, emblema e empresa, recorrem às palavras, que são relacionadas direta ou indiretamente à imagem pictórica como formulação semelhante.

Os preceitos para a invenção de imagens adequadas às empresas são expostos por Paolo Giovio no Diálogo das empresas militares e amorosas, de 1555. Inicialmente, o termo divisa nomeava a divisão feita no campo de um escudo ou de uma bandeira; por extensão, passou a nomear o que era gravado neles. De modo geral, o principal preceito para a invenção da divisa e, depois, da empresa, era ser uma imagem pictórica que não devia ter correspondência com a sentença escrita, diferentemente do emblema, em que a imagem e o epigrama mantêm a relação proporcional de semelhança, 
pois imitam o mesmo conceito por meios, formas e substâncias diferentes. A significação das divisas/empresas tende ao enigma e a dificuldade de sua interpretação levou tratadistas como Scipione Ammirato a afirmar que o esoterismo era decorrência de ela figurar uma filosofia iniciática da cavalaria andante. Mas a divisa já é referida pelo autor latino Vegécio, que tratou das figuras de animais reais e fabulosos usadas em elmos, escudos e estandartes do exército romano. Em De doctrina christiana, II, III, Santo Agostinho fala do seu uso nas bandeiras militares como índice da vontade dos chefes. No diálogo com Lodovico Domenichini em Dialogo dell'emprese militari e amorose, Paolo Giovio afirma algo semelhante, explicando que os antigos usavam cimeiras e ornatos nos elmos e escudos, o que se vê-se claramente em Virgílio quando este faz o catálogo da gente que veio em favor de Turno contra Enéias no canto VIII da Eneida. E Píndaro diz que a Anfiarao levava um dragão no escudo etc. Giovio também lembra o uso de divisas pelos heróis da Canção de Rolando e dos livros de cavalaria da matéria da Bretanha, Amadis de Gaula, Primaleão, Palmeirim, Tirant Le Blanc etc. No tempo de Frederico Barba Roxa houve

...bizarríssimas invenções de cimeiras e pinturas nos escudos, o que em Florença se vê em muitas pinturas de Santa Maria Novella. Mas nesses nossos tempos, depois da vinda do rei Carlos VIII e de Luís XII à Itália, cada homem que seguia o exército, imitando os capitães franceses, tratou de adornar-se de belas e pomposas empresas, com as quais reluziam os cavaleiros, separados companhia de companhia com diversas marcas(...) de modo que as paradas da gente de armas faziam um pomposíssimo e riquíssimo espetáculo e nas batalhas se conhecia o valor e os feitos das companhias (Giovo 36).

No caso, evidencia, o corpo das empresas tinha dupla função: era um ornamento do soldado e um desafio moral lançado ao adversário como um "conceito heróico" marcial, mas não cruel, como diz Tesauro. A seguir, Giovio especifica cinco condições para a "perfeita empresa":

Primeira, justa proporção de alma e de corpo. Segunda, que não seja obscura de modo que seja preciso ter a sibila como intérprete quando se quer entendê-la, nem tão claro que qualquer plebeu a entenda. Terceira, que sobretudo tenha bela forma, a qual se faz muito alegre pondolhe estrelas, sóis, luas, fogo, água, árvores verdejantes, instrumentos mecânicos, animais estranhos e pássaros fantásticos. Quarta, não requer nenhuma forma humana. Quinta, requer o mote é a alma do 
corpo e quer ser comumente em língua diversa do idioma de quem faz a empresa para que o sentimento seja um tanto mais encoberto. Também quer ser breve, mas não tanto que se faça duvidoso, de modo que duas ou três palavras quadram beníssimo, exceto se for em forma de verso ou inteiro ou fragmentado. E para declarar essas condições diremos que a supradita alma e corpo se entende pelo mote e pelo assunto; e estima-se que, faltando ou o assunto à alma ou a alma ao assunto, a empresa não fica perfeita (Giovo 37-38).

Nos tratados, encontram-se outras distinções como preceitos para usos dos emblemas e empresas. Scipione Bargagli, em Dell'imprese (1578), diz algo fundamental: a empresa é "expressão de um conceito", não "um conceito expresso". Por outras palavras, a empresa é uma maneira de figurar ou aplicar o conceito, não a expressão subjetiva dele. Em geral, pressupondo que tanto o emblema quanto a empresa são "expressão de um conceito", não "conceito expresso", os tratadistas opõem seus gêneros, considerando principalmente que são os usos que determinam a diferença. Assim, o emblema sempre é definido como faz Tesauro: documento geral referente à vida humana, ou seja, figuração de noções que têm validade coletiva. Quanto à empresa, figura um propósito heróico particular. No emblema, o mote que encima a alma e o corpo declara a figura para fazer que seja um documento moral de sentido deliberativo ou aconselhamento da ação no futuro. $\mathrm{O}$ emblema também figura casos heróicos, ajuizando-os judicialmente e louvando-os epiditicamente como boas ações exemplares a serem imitadas por todos. Quanto à empresa, como é de uso individual e aristocrático, deve ser equívoca e aguda, com a brevidade que obscurece a qualidade do que está sendo figurado. É justamente por isso que o emblema sem imagens pintadas permanece emblema, bastando a alma para representar publicamente aquilo que se pretende figurar - como ocorre na primeira edição de Emblemata - enquanto a empresa nunca pode dispensar a imagem, pois sem ela o mote fica sem nenhum argumento de semelhança. Dizer Luís XII ferirá de perto e de longe é totalmente hermético, se não se vê o desenho do porco-espinho que significa o conceito visualmente (Tesauro, “Trattato degli emblemi”, ed. cit. 695-696) ${ }^{10}$. Logo, o emblema é

10 Giovio dá o exemplo de Cesare Borgia, que usou uma alma sem corpo: Aut Caesar aut nihil. (Ou César ou nada). Quando César Borgia foi morto em Novara, Fausto Madalena disse, num dístico irônico, que o mote se verificara com a última parte alternativa: Borgia Caesar erat factis et nomine Caesar./Aut nihil aut Caesar dixit,utrumque fuit. Cf. Giovio 38. 
sempre mais inteligível, chão, claro e popular, ao passo que a empresa é mais hermética, aguda, heróica e aristocrática. A de Carlos V tinha a imagem das Colunas de Hércules (Gibraltar) com a sentença latina Plus ultra "Mais além", alegorizando a extensão do seu Império. Quando Carlos V abandonou o cerco de Metz, seus inimigos gravaram outra, com um caranguejo nas Colunas e a sentença Plus citra, "Mais aquém" ou "Mais para trás".

Nos emblemas, o mote declara a figura para fazer dela um documento moral, como no Emblema XLVI de Alciato, em que o mote "Concórdia" refere-se ao corpo onde dois guerreiros romanos seguram o braço direito um do outro, enquanto a alma declara que foi costume segurar o braço direito do inimigo como símbolo da concórdia. Quanto à empresa, o mote obscurece esclarecendo ou explica ocultando, de modo agudo e breve, a propriedade significada. Maria Luisa Doglio lembra que o mote da empresa do nobre napolitano Giovan Vincenzo Pinelli era a inscrição latina REDIBO PLENIOR (Retornarei mais pleno) com a imagem da lua crescente (Doglio, "Introduzione", In Idea delle Perfette Imprese, ed. cit. 78). A empresa do cardeal Richelieu tinha por corpo um globo terrestre, três flores de lis e três cabritos. Por sentença, Stat, "Está parado", "Permanece", "Fica". A empresa funciona por analogia, propondo uma "palavra muda", a imagem pintada de uma coisa valendo por outra, como os cabritos de Richelieu, chamada de "sentido sensível", e uma "palavra inteligível" ou a sentença que metaforiza um conceito, chamada "sentido inteligível".

No emblema, a substância do lugar-comum figurado se conserva sem a imagem pintada, porque o epigrama representa o mesmo assunto. Ou viceversa: é possível usar só o corpo, a imagem pintada, pressupondo-se que a alma ou discurso já é conhecida de todos. De todo modo, no século XVI, o termo emblema podia nomear três coisas: só o texto do epigrama, como na edição de 1521 dos Emblemata; só a imagem pictórica alegórica, como hieróglifo a ser interpretado; o próprio gênero pictórico-discursivo como relação de corpo e alma. Esta última acepção é a que predomina nos séculos XVII e XVIII, embora as duas outras também fossem conhecidas e usadas. É o que se observa, por exemplo, nas descrições de ações de personagens alegóricos que formam narrativas no relato de Simão Ferreira Machado sobre a festa do Triunfo Eucarístico ocorrida em Vila Rica, em 1733. As representações usadas nas festas coloniais são alegorias emblemáticas, como corpos e almas imitados de livros de emblemas. A mesma festa colonial tinha a estrutura de um livro de emblemas decomposto em partes sucessivas postas em movimento, como se o cortejo fosse uma figura das páginas que 
se iam virando, dando a ver imagens e discursos para o público. Também os retábulos de igrejas coloniais, como os da Matriz de Antônio Dias ou da Igreja do Pilar, em Ouro Preto, são dispostos como páginas abertas de um livro de emblemas posto em pé para mostrar narrativas exemplares de vidas de santos. $\mathrm{O}$ espectador que vai do pára-vento até o altar vê, à direita e à esquerda, formas pictóricas e plásticas dispostas linearmente como corpos de livros de emblemas. A alma ou o discurso das vidas dos santos representados nelas fica por conta da sua memória ${ }^{11}$.

Assim, se a substância do emblema se conserva sem a imagem pintada, porque o epigrama exprime o assunto; ou sem o epigrama, pois também a imagem o figura, a empresa não pode existir sem a imagem, pois sem ela o mote fica sem o argumento da semelhança. No entanto, o mote da empresa do pai de Andrea de Cápua, Duque di Termoli, era NEC SPE NEC METU. Pintado no campo branco do escudo (Giovo 131) sem corpo, era considerado perfeitíssimo, belíssimo. No emblema, o epigrama é mais digno de louvor quando é inventado pelo autor. Na empresa, o mote é mais louvável quando é de outro autor. Sendo popular, o emblema admite grande variedade de figuras históricas, fabulosas, artificiais, naturais, quiméricas; e não recusa a representação do corpo humano, como o de Ganimedes, que sai, ou o de Faetonte, que cai, ou o de Taís, que trai. Quanto à empresa, é considerada mais perfeita quando a figura é mais natural e única, sem possibilidade de representação do corpo humano, admitindo-se, no entanto, partes dele (Tesauro, Il Cannocchiale Aristotelico ed.cit. 696).

O lugar mais apropriado para o uso de emblemas são as tabuletas e os quadros postos à vista do povo; também paredes de salas e igrejas, frisos, arcos, aparatos festivos. O lugar apropriado para usar a empresa é o escudo,

11 Referindo-se a Imago Primi Saeculi Societatis Jesus a Provincia Flandro-Belgica eiusdem Societatis Repraesentata (Anvers: Balthasar Moretus, 1640), livro de emblemas que celebra o jubileu da Companhia de Jesus, Marc Fumaroli escreve: “...este volumoso in-folio é concebido pela imaginação plástica de seus autores como um monumento arquitetônico, com sua fachada (o frontispício), seu peristilo (a dedicatória e o prefácio) e suas seis ‘capelas' que o leitor-peregrino visitará em seguida, mas que é preciso imaginar como repartidas em dois grupos de três de cada lado de uma nave central. O espaço da leitura luta por assim dizer com a abstração do impresso para reconstituir, na disposição das páginas e da ilustração delas, a experiência da palavra ecoante numa arquitetura.O sentimento de entrar num lugar, de deslocar-se nele, liga-se muito naturalmente à audição interior do texto lido, a um movimento dos olhos percorrendo as imagens gravadas como se se tratasse de quadros, de esculturas ou de monumentos ornamentais dispostos contra as paredes...". Cf. Fumaroli 75-111. 
exprimindo o conceito heróico de quem o leva; e também as bandeiras. No século XV, Ângelo Poliziano especializou-se em gravar divisas hieroglíficas em punhos de espada, anéis e outros objetos de uso pessoal.

Para terminar, lembremos que o gênero emblema foi "moralizado" na ação contra-reformista. O primeiro livro de emblemas "moralizados" é o de Georgette de Montenay, Emblèmes ou devises chrestiennes, publicado em Lyon em 1571. Como exemplo dessa moralização, leia-se o que propõe o seguinte mote, Figuras do Amor Divino substituindo Cupido, que é seguido dessa alma:

Il est besoin chercher de tous costés

De l'appetit pour ces gens degoustés:

L'un attiré sera par la peinture,

L'autre y ioindra poesie, et ecriture...

("mainte honneste et dame et demoiselle")

...pourront accomoder

A leurs maisons, aux meubles s'en aider,

Rememorans tousiuous quelque passage

Du saint escrit bien propre à leur usage,

Dont le Seigneur sera glorifié,

Et cependant quelqu'un edifié ${ }^{12}$.

A apropriação contra-reformista do emblema é realizada no século XVI principalmente pela Companhia de Jesus e substitui o nu de imagens de deuses greco-latinos por imagens cristãs vestidas no corpo. Ao mesmo tempo, as referências à poesia e à prosa antigas são substituídas, na alma, por trechos das Escrituras e de hagiografias cristãs, como exempla da boa conduta moral da vida beata oposta à vida libertina. Desde a segunda metade do século XVI, os jesuítas passaram a definir a representação - oratória, poética, pictórica, plástica, musical etc.- como theatrum sacrum ou encenação de tópicas da história definida como história sacra. Nos usos católicos dos séculos XVI, XVII e XVIII, o gênero emblema torna-se veículo para a figuração de dogmas, mistérios, preceitos, exemplos, virtudes e vidas de santos da "Roma triunfante". O corpo do emblema passa a pressupor a teologia como fundamento da verossimilhança das imagens em uma espécie de ut theologia 
poesis. Em 1595, o Pe. Jerônimo Nadal, da Companhia de Jesus, publicou em Anvers a segunda edição de Adnotationes et meditationes in Evangelia quae in sacrosancto missae sacrifício toto anno leguntur. O livro mantém a tripla estrutura do emblema - mote, corpo, alma- sendo inventado como coletânea de "composições de lugar" ou imagens e discursos que figuram lugares-comuns doutrinários. O mote ou título indica uma referência das Escrituras -por exemplo, "Adoração dos Magos". Logo abaixo, o corpo é constituído de quadros onde cenas, coisas, animais, personagens e ações figuram os lugares-comuns indicados pelo título. As imagens são classificadas por letras (A, B,C...Z)- por exemplo, "Belém" por A; "a estrela" por B; "três reis magos" por C; "Maria e o Menino" por D; "boi e burro" por E, etc. No rodapé da página, as letras são dispostas em colunas, com a identificação da imagem e seus acidentes. Por exemplo, "A. Belém para onde vão os Magos"; "B. A estrela que lhes mostrou onde JESUS estava"; "C. Os Magos que chegaram a Belém"; "D. Maria sozinha com o Menino na manjedoura"; "E. O boi e o asno no presépio", etc. A seguir, num capítulo ordenado em três partes, lê-se, na primeira, a lectio (o texto do Evangelho indicado pelo mote ou título e, nas margens, variantes dos Evangelhos sinóticos); na segunda parte do capítulo, chamada adnotatio, encontram-se desenvolvimentos das identificações feitas pelas letras na parte inferior da prancha. A terceira parte, chamada meditatio, é um sermão muito breve que constitui o leitor-ouvinte em espectador, concentrando-lhe a atenção na imagem que se evidencia como "composição de lugar". No caso, Nadal utiliza o modelo do emblema como arte da memória dos lugares da meditação espiritual prescrita por Inácio de Loyola nos Exercícios Espirituais (cf. Chatelain 154-155) ${ }^{13}$.

Tais usos teológico-políticos do emblema estendem-se até o final do século XVIII, quando Deus morre. Desde então, o emblema religioso ou nãoreligioso é um gênero morto. Como as empresas, cuja alma foi definitivamente separada do corpo na Revolução francesa.

13 Cf. Também Pierre-Antoine Fabre. Ignace de Loyola. Le lieu de l'image. Le problème de la composition de lieu dans les pratiques spirituelles et artistiques jésuites de la seconde moitié du XVIe siècle. 


\section{BIBLIOGRAFÍA}

Alciat, André. Les Emblèmes. Fac-simile de l'édition lyonnaise Macé-Bohomme de 1551. Paris: Klincksieck, 1997.

Artémidore d'Éphèse. La clef des songes,ou les cinq livres de l'intérprétation des songes, rêves et visions. Traduits du grec et commentés par Henry Vidal. Paris, 1921.

Buxó, José Pascual. "El resplandor intelectual de las imágenes: jeroglifica y emblemática". In Juegos de Ingenio y Agudeza. La Pintura Emblemática de la Nueva España. México: Museo Nacional de Arte, 1994.

Chatelain, Jean-Marc. Livres d'emblèmes et de devises. Une anthologie (1531-1735). Paris: Klincksieck, 1993.

Fabre, Pierre-Antoine. Ignace de Loyola. Le lieu de l'image. Le problème de la composition de lieu dans les pratiques spirituelles et artistiques jésuites de la seconde moitié du XVIe siècle. Paris: Librairie Philosophique J. Vrin, 1992.

Fumaroli, Marc. "Baroque et classicisme: l'Imago Primi Saeculi Societatis Jesu (1640) et ses adversaires". In Questionnement du baroque. Louvain A. Vermeylen, 1986.

Giovo, Paolo. Dialogo dell 'imprese militari e amorose. A cura di Maria Luisa Doglio. Roma: Bulzoni Editore, 1978.

Gombrich, E. H. “The personification of ideas”. In Gombrich on the Renaissance: Volume 2: Symbolic Images. First edition 1972. Second Impression 1993. London: Phaidon Press Limited, pp. 126-127.

Horapolo. Hieroglyphica. Ed. de Jesús Maria González de Zárate. Madrid: AKAL S.A., 1991.

Klein, Robert. "La théorie de l'expression figurée dans les traités italiens sur les 'imprese', 1555-1612"; "Giudizio et Gusto dans la théorie de l'art au Cinquecento". In La forme et l'intelligible. Préface de A. Chastel. Paris: Gallimard, 1970 (Trad. brasileira A Forma e o Inteligivel. São Paulo: EDUSP, 1998).

Machado, Simão Ferreira. Triunfo Eucarístico, Exemplar da Cristandade Lusitana em pública exaltação da Fé na solene Trasladação do Diviníssimo Sacramento da Igreja da Senhora do Rosário, para um novo Templo da Senhora do Pilar em Vila Rica, Corte da Capitania das Minas aos 24 de maio de 1733 etc. In José Aderaldo Castello. O Movimento Academicista no Brasil: 1641-1820/22. São Paulo: Conselho Estadual de Cultura, 1969.

Praz, Mario. Studi sul Concettismo. Milano, Carabba Editore, 1934.

Ripa, Cesare. Iconologia. A cura di Piero Buscaroli. Prefazione di Mario Praz. Milano: TEA, 1991.

Rossi, Paolo. Clavis Universalis. Arts de la mémoire, logique combinatoire et langue universelle de Lulle à Leibniz. Trad. Patrick Vighetti. Paris: Jérôme Millon, 1993.

Rubens, P. “Carta a Justus Sustermans”. Cit. por Gombrich, E. H. Icones Symbolicae. 2nd. impression. London: Phaidon, 1993.

Santa María, Fray Juan de. Tratado de República y Policía cristiana. Para Reyes y Príncipes y para los que en el gobierno tienen sus veces. Madrid: Imprenta Real, 1615. 
Schopenhauer, Arthur. O mundo como vontade e representação. Primeiro Tomo. Quatro livros, seguidos de um apêndice que contém a crítica da filosofia kantiana. Tradução, apresentação, notas e índices de Jair Barboza. São Paulo: Editora UNESP, 2005.

Solórzano Pereira, Juan de. Príncipe Perfeito. Emblemas de D. João de Solórzano. Ed. facsimilada do manuscrito da Biblioteca Nacional do Rio de Janeiro oferecido ao Príncipe D. João em 1790. Prefácio, introdução, comentário e índices por Maria Helena de Teves Costa Ureña Prieto. Instituto de Cultura e Língua Portuguesa, Biblioteca Nacional, 1985.

Tasso, Torquato. Il Conte overo de l'imprese (1594). Cit, por Maria Luisa Doglio. In Paolo Giovio. Dialogo dell'imprese militari e amorose. A cura di Maria Luisa Doglio. Roma: Bulzoni editore, 1978.

Tesauro, Emanuele. “Trattato degli emblemi”. In Il Cannocchiale Aristotelico. 5 ed. Revista pelo autor. Torino, Zavatta, 1670.

Idea delle Perfette Imprese. Testo inedito a cura di Maria Luisa Doglio. Firenze, Leo. S. Olschki, 1970.

Valeriano Bolzani, Giovanni Pierio. Les hieroglyphiques. Autrement, commentaires des lettres et figures sacrées des Aegyptiens \& autres nations etc. Par J. de Montlyart. Lyon: Paul Frellon, 1615. 